\title{
Pengaruh Kualitas Website E-Commerce, Kepercayaan, Persepsi Risiko dan Norma Subyektif terhadap Minat Beli Secara Online di bukalapak.com
}

\author{
Ady Achadi*, Mayla Surveyandini, Agus Prabawa \\ Fakultas Ekonomika dan Bisnis \\ Universitas Wijayakusuma Purwokerto, Banyumas \\ *correspondence email: adyachadi@unwiku.ac.id
}

\begin{abstract}
Abstrak. Penelitian ini bertujuan menganalisis pengaruh kualitas website e-commerce, kepercayaan, persepsi risiko, dan norma subjektif terhadap minat beli di bukalapak.com. Jenis penelitian adalah kuantitatif. Teknik pengambilan sampel menggunakan purposive sampling. Metode penelitian menggunakan Structural Equational Modeling (SEM). Hasil penelitian menunjukkan bahwa kualitas website e-commerce, kepercayaan dan persepsi risiko berpengaruh positif signifikan terhadap minat beli di bukalapak.com. Norma subjektif tidak berpengaruh terhadap minat beli secara online di bukalapak.com. Temuan ini mengimplikasikan kebijakan perlunya membuat dan mengatur website yang praktis dengan tampilan yang lebih baik, menggunakan bahasa yang mudah dipahami dan website mudah diakses oleh konsumen. Selain itu, memberikan jaminan keamanan produk dan jaminan terhadap risiko kerusakan serta kehilangan produk yang dibeli oleh konsumen.
\end{abstract}

Kata kunci: Bukalapak.com; E-commerce; Konsumen

\begin{abstract}
This study aims to analyze the effect of e-commerce website quality, trust, risk perception, and subjective norms on buying interest at Bukalapak.com. This type of research is quantitative. The sampling technique used was purposive sampling. The research method uses Structural Equation Modeling (SEM). The results showed that the quality of the e-commerce website, trust and risk perception have a significant positive effect on buying interest at Bukalapak.com. Subjective norms have not significant effect on online buying interest at Bukalapak.com. This finding implies the policy of the need to create and manage a practical website with a good appearance, using language that is easy to understand and the website is easily accessible to consumers. In addition, it provides product safety guarantees and guarantees against the risk of damage and loss of products purchased by consumers.
\end{abstract}

Keywords: Bukalapak.com; E-commerce; consumers.

\section{PENDAHULUAN}

Di era digital sekarang ini, internet telah menjadi sumber utama informasi yang telah mengubah perilaku konsumen dalam melakukan pembelian dari secara konvensional berubah menjadi online. Menurut Afrisia (2018) perkembangan e-commerce di Indonesia melejit pesat dengan jumlah transaksi mencapai US $\$ 4,89$ miliar pada awal tahun 2016. Hasil survei yang dilakukan Greenberg Brand Strategy menunjukkan bahwa 76 persen pengguna internet di Indonesia berbelanja secara online. Data tersebut menunjukkan adanya minat untuk melakukan pembelian secara online. Minat untuk membeli merupakan tendensi konsumen untuk melakukan pembelian suatu produk secara aktual. Sutisna (2005) mengemukakan bahwa pengukuran minat konsumen untuk melakukan pembelian merupakan suatu hal yang penting dalam pengembangan strategi pemasaran. Minat membeli merupakan tahap terakhir dari rangkaian proses keputusan pembelian konsumen. Proses ini akan dimulai dari munculnya kebutuhan akan suatu produk dan dilanjutkan dengan pemrosesan informasi oleh konsumen selanjutnya konsumen akan mengevaluasi produk tersebut. Sebagai hasil dari kegiatan evaluasi alternatif, konsumen mulai mengarah pada niat untuk membeli. Menurut Morissan (2010) keinginan membeli secara umum didasarkan pada upaya mencocokkan motif pembelian dengan atribut produk atau merek yang tengah dipertimbangkan dengan melibatkan aspek psikologis, seperti motivasi, persepsi, sikap, dan integrasi yang dipengaruhi oleh berbagai faktor.

Saat ini, persaingan bisnis di antara e-commerce di Indonesia semakin ketat. Hal ini ditunjukkan dengan banyaknya e-commerce yang menjadi kompetitor Bukalapak.com, seperti Tokopedia, Lazada Indonesia, Elevenia, Qoo10, Rakuten.co.id., Blibli.com, Matahari Mall.com, JD.ID, Shopee, dan lain-lain. Pada tahun 2019 jumlah pengunjung di Bukalapak sebanyak 34 juta orang. Perlu diketahui bahwa berdirinya Bukalapak ditujukan sebagai lapak online bagi pelaku UMKM. Namun dengan berkembangnya permintaan dari konsumen yang disebabkan makin banyaknya kebutuhan kini Bukalapak menjual berbagai macam produk, sehingga bukalapak berpotensi memiliki konsumen yang lebih banyak. Dengan demikian, secara purposive sampling penelitian ini memilih e-commerce bukalapak sebagai obyek penelitian. Dalam mewujudkan keputusan konsumen untuk membeli di bukalapak peneliti menduga bahwa minat membeli di bukalapak dipengaruhi oleh kualitas web site, kepercayaan, persepsi risiko dan norma subyektif. 
Kualitas website e-commerce adalah persepsi terhadap kualitas teknis, isi, dan tampilan dari suatu website (Al-Qeisi et al. 2014). Studi empiris Ghafiki \& Setyorini (2017) menemukan bahwa penilaian responden terhadap kualitas website memengaruhi pembelian konsumen secara online. Selain kualitas website e-commerce, faktor lainnya yang diduga memengaruhi minat beli secara online adalah kepercayaan. Menurut Kim et al. (2003) kepercayaan didefinisikan sebagai rasa percaya konsumen yang timbul karena merasa puas dan nyaman atas pemenuhan tanggung jawab penjual pada transaksi melalui media $e$ commerce

Selain itu, persepsi resiko diduga mempengaruhi minat beli secara online. Peter \& Olson (2012) mengemukakan bahwa persepsi risiko adalah konsekuensi yang tidak diharapkan dan ingin dihindari konsumen saat membeli dan menggunakan produk. Walaupun e-commerce memberikan banyak kemudahan dalam hal transaksi jual beli produk secara online, tetapi seringkali memunculkan berbagai permasalahan yang banyak dikeluhkan oleh para konsumen, diantaranya adalah risiko produk yang tidak sesuai dengan pesanan, risiko produk rusak pada saat pengiriman dan maraknya penipuan. Menurut Kautonen \& Karjaluoto (2008) tingkat ketidakpastian, ketergantungan, dan risiko yang dihadapi oleh konsumen yang melakukan pembelian produk secara online cenderung lebih tinggi dibandingkan dengan pembelian produk secara offline. Oleh karena itu, keamanan bertransaksi secara online merupakan faktor penting yang banyak dipertimbangkan oleh konsumen atau calon konsumen sebelum memutuskan untuk membeli melalui e-commerce. Studi empiris Haekal \& Widjajanta (2016) mengukur variabel persepsi risiko menggunakan beberapa indikator, yaitu risiko kinerja, risiko keuangan, risiko fisik, risiko sosial, risiko psikologikal dan risiko waktu. Hasil penelitiannya menemukan bahwa persepsi risiko berpengaruh negatif dan signifikan terhadap minat membeli secara online pada pengunjung website classifieds di Indonesia.

Selanjutnya, variabel yang diindikasikan kuat dapat memengaruhi minat beli secara online adalah norma subyektif. Norma subyektif merupakan persepsi atau pandangan seseorang terhadap kepercayaankepercayaan orang lain yang akan memengaruhi minat untuk melakukan atau tidak melakukan perilaku yang sedang dipertimbangkan (Jogiyanto, 2007). Terkait dengan norma subyektif, Kotler \& Keller (2009) mengemukakan bahwa faktor sosial seperti kelompok referensi, keluarga, dan peran sosial serta status mempengaruhi perilaku konsumen dalam pembelian. Temuan Binalay (2016) menunjukkan bahwa norma subyektif berpengaruh positif dan signifikan terhadap minat konsumen dalam melakukan pembelian secara online melalui e-commerce.
Berdasarkan uraian di atas, maka tujuan dari penelitian ini adalah membuktikan apakah kualitas website e-commerce, kepercayaan, persepsi risiko dan norma subyektif berpengaruh terhadap minat beli secara online pada market place bukalapak.com.

\section{METODE}

Jenis penelitian ini adalah kualitatif. Obyek penelitian adalah mahasiswa Fakultas Ekonomika dan Bisnis Universitas Wijayakusuma Purwokerto. Variabel dependent adalah minat beli secara online (indikator pengukuran yaitu perhatian, ketertarikan, keinginan yang kuat). Sementara itu, variabel independent adalah kualitas website e-commerce (indikator pengukuran yaitu kemudahan navigasi, kehandalan, estetika), kepercayaan (indikator pengukuran yaitu persepsi integritas, persepsi kebaikan, persepsi komptensi), persepsi risiko (indikator pengukuran yaitu barang berfungsi dengan baik, tidak menipu, jaminan pengiriman, bonafide, keamanan data, pengiriman cepat) dan norma subyektif (indikator pengukuran yaitu pengalaman teman, dukungan keluarga, pengaruh kelompok refensi, Pengaruh media sosial). Pengukuran variabel independent dan dependent menggunakan skala Likert. Penentuan sampel menggunakan purposive random sampling. Menurut Sugiyono (2014) purposive sampling adalah teknik penentuan sampel dengan pertimbangan tertentu. Adapun jumlah sampel sebanyak 100 mahasiswa. Beberapa pertimbangan atau kriteria sampel dalam penelitian ini adalah mahasiswa S1 Fakultas Ekonomika dan Bisnis Universitas Wijayakusuma Purwokerto yang mengetahui dan mengunjungi website bukalapak.com.

Selanjutnya untuk melakukan pengujian signifikansi pengaruh variabel kualitas website $e$ commerce, kepercayaan, persepsi risiko, dan norma subyektif terhadap minat beli dalam penelitian ini dilakukan menggunakan analisis Structural Equational Modelling (SEM) dengan bantuan software Analysis Moment of Structural (AMOS). Structrual Equation Modeling (SEM), jumlah sampel yang diambil dari populasi ditentukan sebesar 5-10 kali jumlah indikator atau variabel yang digunakan dalam model analisis (Hair, 2009).

\section{HASIL DAN PEMBAHASAN}

\section{Analisis Terhadap Model SEM}

Berdasarkan analisis output yang dihasilkan model SEM secara utuh, selanjutnya dapat digambarkan hasil sebagai berikut: 


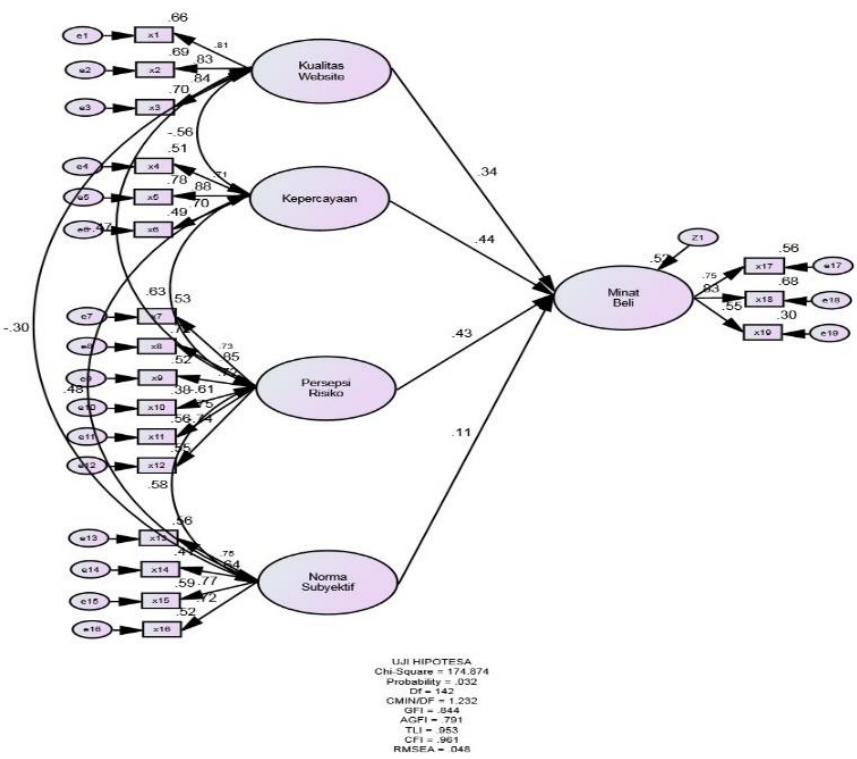

Gambar 1. Analisis Full Model SEM

\section{Evaluasi Keseuaian Model (Goodness of Fit)}

Pengujian mengenai kesesuaian model dilakukan melalui beberapa tahap untuk memperoleh kriteria goodness of fit, dengan hasil sebagai berikut:

\section{Evaluasi Asumsi SEM}

1. Evaluasi Normalitas Data

Pengujian normalitas data penelitian ini disajikan dalam Tabel 1.

Tabel 1. Uji Normalitas terhadap Data Penelitian

\begin{tabular}{lrrrrrr}
\hline Varibael & Min & Max & \multicolumn{1}{l}{ Skew } & \multicolumn{1}{c}{ c.r. } & \multicolumn{1}{l}{ Kurtosis } & \multicolumn{1}{c}{ c.r. } \\
\hline x6 & 2,000 & 5,000 &,- 315 & $-1,286$ &, 111 &, 226 \\
x5 & 2,000 & 5,000 &,- 200 &,- 815 &,- 177 &,- 361 \\
x4 & 2,000 & 5,000 &,- 091 &,- 373 &,- 134 &,- 274 \\
x12 & 2,000 & 5,000 &, 377 & 1,540 &,- 378 &,- 772 \\
x11 & 2,000 & 5,000 &, 489 & 1,998 &, 057 &, 116 \\
x8 & 2,000 & 5,000 &,- 159 &,- 650 &,- 345 &,- 704 \\
x7 & 2,000 & 5,000 &,- 208 &,- 848 &,- 148 &,- 302 \\
x10 & 2,000 & 5,000 &, 528 & 2,157 &,- 252 &,- 515 \\
x9 & 2,000 & 5,000 &,- 354 & $-1,445$ &,- 258 &,- 527 \\
x19 & 1,000 & 5,000 &, 090 &, 368 &,- 811 & $-1,656$ \\
x18 & 2,000 & 5,000 &, 177 &, 723 &,- 281 &,- 573 \\
x17 & 2,000 & 5,000 &,- 185 &,- 755 &,- 099 &,- 202 \\
x14 & 2,000 & 5,000 &,- 606 & $-2,475$ &, 091 &, 186 \\
x13 & 2,000 & 5,000 &,- 572 & $-2,335$ &,- 061 &,- 124 \\
x16 & 2,000 & 5,000 &,- 422 & $-1,722$ &, 099 &, 203 \\
x15 & 2,000 & 5,000 &,- 602 & $-2,456$ &, 044 &, 090 \\
x3 & 2,000 & 5,000 &, 552 & 2,254 &,- 059 &,- 121 \\
x2 & 2,000 & 5,000 &, 334 & 1,363 &,- 311 &,- 635 \\
X1 & 2,000 & 5,000 &, 528 & 2,1156 &,- 260 &,- 531 \\
& Multivariate & & & & 12,400 & 2,195 \\
\hline
\end{tabular}

Sumber : Output AMOS

Tabel 1 memperlihatkan bahwa setiap indikator variabel laten memiliki nilai critical ratio skewness kurang dari $\pm 2,58$, yang berati bahwa secara univariate data terdistribusi secara normal. Selanjutnya, hasil pengujian normalitas secara multivariate pada kolom critical ratio juga kurang dari nilai batas $\pm 2,58$, yang menunjukkan data penelitian secara multivariate juga dinyatakan berdistribusi normal.

\section{Univariate Outliers}

Dari hasil output analisis deskriptif diketahui bahwa nilai $z$-score dari semua indikator pembentuk variabel laten dalam penelitian lebih kecil dari $\pm 3,00$ sehingga bisa dibuktuikan bahwa data dalam penelitian ini bebas dari univariate outliers.

3. Multivariate Outliers

Tahap selanjutnya yaitu mengevaluasi terhadap multivariate outliers yang dilakukan karena walaupun data yang dianalisis telah bebas univariate outliers, tetapi obeservasi-observasi tersebut masih mungkinakan menjadi outliers apabila sudah dikombinasikan. Evaluasi Multivariate outliers dilakukan dengan membandingkan antara nilai mahalonobis distance dengan nilai chi-square tabel menggunakan $\mathrm{df}=19$ (jumlah indikator) dan tingkat error $=0,001 \quad(19 ; 0,001=43,82)$. Berdasarkan kriteria tersebut, diperoleh bahwa nilai terbesar dari mahalonobis distance adalah 41,478 atau tidak melebihi dari nilai chi-square tabel, hal ini membuktikan bahwa data penelitian bebas dari multivariate outliers.

4. Evaluasi Multicolinearity dan Singularity

Tahap terakhir melakukan evaluasi multicolinearity dan singularity berupa kombinasi variabel berdasarkan pada hasil analisis SEM melalui nilai determinant of sample covariance matrix. Kecilnya nilai Determinan mengindikasikan adanya multicolinearity dan singularity. Berdasarkan hasil analisis SEM dengan bantuan software AMOS diperoleh bahwa nilai determinant of sample covariance matrix dalam penelitian ini adalah 0,003 lebih besar dari nol, sehingga dapat dinyatakan tidak terdapat multicolinearity dan singularity, dengan demikian data dalam penelitian ini layak digunakan.

\section{Uji Kesesuaian Model (Goodness of Fit)}

Pengujian kesesuaian model memperlihatkan bahwa konstruk dalam model penelitian telah sesuai (fit) dengan data penelitian. Adapun ringkasan hasil pengujian goodness of fit dapat dilihat pada Tabel 2.

Tabel 2. Ringkasan Hasil Uji Kesesuaian Model (Goodness of Fit)

\begin{tabular}{lccc}
\hline Goodness of Fit Index & Hasil Analisis & Cut of Value & Evaluasi Model \\
\hline$X^{2}$ Chi-Square & 174,874 & $<170,809$ & Marjinal \\
Probability & 0,032 & $>0,05$ & Marjinal \\
CMIN/DF & 1,232 & $<2,00$ & Baik \\
GFI & 0,844 & $>0,90$ & Marjinal \\
AGFI & 0,791 & $>0,90$ & Marjinal \\
TLI & 0,953 & $>0,95$ & Baik \\
CFI & 0,961 & $>0,95$ & Baik \\
RMSEA & 0,048 & $<0,08$ & Baik \\
\hline
\end{tabular}

Sumber: Output AMOS

Tabel 2 menunjukkan uji Goodness of Fit dari 8 indikator yang dinyatakan bahwa model sudah tepat. $X^{2}$ Chi-Square, Probability, GFI, AGFI dinyatakan lolos 
uji Goodness of Fit dengan kriteria marjinal, sedangkan CMIN/DF, TLI, CFI dan RMSEA dengan kriteria baik.

\section{Uji Validitas}

Uji validitas dilakukan dengan melihat nilai loading factor dari indikator variabel kualitas website, kepercayaan, persepsi risiko, norma subyektif maupun minat beli yang menunjukan masing-masing nilainya lebih besar dari 0.500. Dengan demikian, dapat dikatakan semua indikator dari setiap variabel tersebut terbukti valid sehingga dapat digunakan sebagai alat pengumpul data untuk penelitian ini. Berdasarkan hasil penghitungan uji reliabilitas diketahui juga bahwa koefisien reliabilitas dari setiap variabel kualitas website, kepercayaan, persepsi risiko, norma subyektif maupun minat beli nilainya lebih besar dari 0.700. Dengan demikian, maka konstruk dari setiap variabel dalam penelitian ini dinyatakan reliable sehingga dapat digunakan sebagai alat pengumpul data. Selanjutnya, berdasarkan hasil penghitungan uji variance extract diketahui bahwa nilai variance extract masing-masing indikator variabel kualitas website, kepercayaan, persepsi risiko, norma subyektif maupun minat beli lebih besar dari 0.500. Dengan demikian, maka konstruk dari setiap variabel dalam penelitian ini dinyatakan layak untuk digunakan dalam menguji hubungan kausal dalam penelitian.

\section{Pengujian Hipotesis}

Berdasarkan output analisis model SEM secara utuh, selanjutnya dapat disarikan ringkasan hasil hubungan kausal antar variabel dalam penelitian ini seperti tertera pada Tabel 3 .

Tabel 3. Standarized Regression Weight untuk Pengujian Hipotesis

\begin{tabular}{llccc}
\hline Hubungan Kausal & & C.R & p-value \\
\hline Minat_Beli <-- & Kualitas_Website (KW) & 2,518 & 0,012 \\
Minat_Beli <-- & Norma_Subyektif (NS) & 0,801 & 0,423 \\
Minat_Beli <-- & Kepercayaan (KPC) & 2,594 & 0,009 \\
Minat_Beli <-- & Persepsi_Risiko (PR) & 2,649 & 0,008 \\
\hline
\end{tabular}

Sumber: Output AMOS

\section{Pengaruh Kualitas Website Terhadap Minat Beli}

Merujuk Tabel 3 menunjukkan bahwa $p$-value untuk pengaruh kualitas website terhadap minat beli adalah 0,012 lebih kecil dari 0,05. Oleh karena itu, dapat disimpulkan bahwa kualitas website e-commerce berpengaruh positif signifikan terhadap minat konsumen untuk melakukan pembelian secara online $\mathrm{di}$ Bukalapak.com. Hubungan kausal tersebut membuktikan bahwa semakin baik kualitas website $e$ commerce, maka akan semakin kuat minat konsumen untuk melakukan pembelian secara online di Bukalapak.com. Secara teoritis, temuan ini sejalan dengan Chang et al., (2014) yang menyatakan bahwa kualitas situs web (website) menjadi faktor kunci dalam perdagangan elektronik (e-commerce) karena persepsi pelanggan terhadap kualitas situs web akan berdampak positif terhadap niat konsumen dalam menggunakan situs, dan secara langsung akan mempengaruhi niat pembelian secara online. Secara empiris, temuan ini mendukung penelitian Hendrayana \& Santika (2016) dan Noronha \& Rao (2017) yang juga membuktikan bahwa kualitas laman (website) mempunyai pengaruh yang positif dan signifikan terhadap niat membeli secara online pada situs belanja online.

\section{Pengaruh Kepercayaan Terhadap Minat Beli}

Merujuk Tabel 3 menunjukkan bahwa $p$-value untuk pengaruh kepercayaan terhadap minat beli adalah 0,009 juga lebih kecil dari 0,05. Oleh karena itu, dapat disimpulkan bahwa kepercayaan berpengaruh positif dan signifikan terhadap minat konsumen untuk melakukan pembelian secara online di Bukalapak.com. Hubungan kausal tersebut membuktikan bahwa semakin tinggi tingkat kepercayaan konsumen, maka akan semakin kuat minat konsumen untuk melakukan pembelian secara online di Bukalapak.com. Secara teoritis, temuan ini sejalan dengan Ardyanto et al., (2015) yang menyatakan bahwa hal utama yang dipertimbangkan seorang pembeli ketika melakukan kegiatan belanja secara online adalah apakah konsumen percaya terhadap situs yang menyediakan fasilitas layanan online shop dan percaya pada penjual online yang ada di dalam situs tersebut. Secara empiris, temuan ini mendukung penelitian Hendrayana \& Santika (2016) bahwa kepercayaan mempunyai pengaruh yang positif dan signifikan terhadap niat membeli secara online.

\section{Pengaruh Persepsi Risiko Terhadap Minat Beli}

Merujuk Tabel 3 menunjukkan bahwa p-value untuk pengaruh persepsi risiko terhadap minat beli adalah 0,008 lebih kecil dari 0,05. Oleh karena itu, dapat disimpulkan bahwa persepsi risiko berpengaruh positif dan signifikan terhadap minat konsumen untuk melakukan pembelian secara online di Bukalapak.com. Hubungan kausal tersebut membuktikan bahwa semakin baik tingkat persepsi risiko maka akan semakin kuat minat konsumen untuk melakukan pembelian secara online di Bukalapak.com. Hubungan kausal tersebut menunjukkan bahwa semakin baik persepsi konsumen terhadap risiko yang mungkin akan dihadapi, maka akan semakin kuat minat konsumen untuk melakukan pembelian secara online di Bukalapak.com. Secara teoritis, temuan ini sejalan dengan Aliyar \& Mutambala (2015) dan Haekal \& Widjajanta (2016) bahwa persepsi risiko berpengaruh signifikan terhadap niat konsumen untuk melakukan pembelian produk-produk kosmetik secara online.

\section{Pengaruh Norma Subyektif Terhadap Minat Beli}

Merujuk Tabel 3 menunjukkan bahwa p-value untuk pengaruh norma subyektif terhadap minat beli adalah 0,423 lebih besar dari 0,05. Oleh karena itu, dapat 
disimpulkan bahwa norma subyektif tidak berpengaruh terhadap minat konsumen untuk melakukan pembelian secara online di Bukalapak.com. Hubungan kausal tersebut menunjukkan bahwa semakin baik persepsi konsumen terhadap norma subyektif tidak selalu diikuti dengan semakin kuatnya minat konsumen untuk melakukan pembelian secara online di Bukalapak.com. Secara teoritis, temuan ini tidak sejalan dengan Hasbullah et al., (2016) bahwa norma subyektif berpengaruh positif dan signifikan terhadap niat konsumen untuk berbelanja secara online (intention shopping online). Di sisi lain, hasil penelitian ini sejalan dengan studi yang dilakukan oleh Idris \& Kasmo (2017) yang menunjukkan hasil bahwa norma subyektif tidak berpengaruh terhadap minat nasabah untuk memiliki kartu kredit Bank.

\section{SIMPULAN}

Berdasarkan hasil analisis SEM, maka dapat diambil kesimpulan bahwa kualitas website e-commerce, kepercayaan, dan presepsi risiko berpengaruh positif dan signifikan terhadap minat konsumen untuk melakukan pembelian secara online di Bukalapak.com. Sementara itu, norma subyektif tidak berpengaruh signifikan terhadap minat konsumen untuk melakukan pembelian secara online di Bukalapak.com. Temuan ini mengimplikasikan kebijakan perlunya membuat dan mengatur desain website yang praktis dengan tampilan yang menarik, menggunakan bahasa yang mudah dimengerti dan mampu memberikan kemudahan dalam mengakses website bagi konsumen. Selain itu, memberikan jaminan keamanan produk dan jaminan terhadap risiko kerusakan serta kehilangan produk yang dibeli oleh konsumen.

\section{DAFTAR PUSTAKA}

Afrisia, R. Z. (2018). CEO Living Social Indonesia: Flash Site "Meledak" Dua Tahun Lagi, Viva.co.id.

Ardyanto, D. (2015). Pengaruh kemudahan dan kepercayaan menggunakan E-commerce terhadap keputusan pembelian online (Survei Pada Konsumen www. petersaysdenim. com). Jurnal Administrasi Bisnis, 22(1), 1-8.

Aliyar, S., \& Mutambala, C. (2015). Consumers' Online Purchase Intention in Cosmetic Products, Thesis, Linnaeus University, Swedia.

Al-Qeisi, K., Dennis, C., Alamanos, C., \& Jayawardhena, C. (2014). Website Design Quality and Usage Behavior: Unified Theory of Acceptance and Use of Technology, Journal of Business Research, 67(11), 2282-2290. https://doi.org/10.1016/j.jbusres.2014.06.016

Binalay, A. G. (2016). Pengaruh Sikap, Norma Subyektif dan Motivasi Terhadap Minat Beli Secara Online pada Mahasiswa Fakultas Ekonomi dan Bisnis di Manado, Jurnal EMBA, 4(1), 395-
406.

https://doi.org/10.35794/emba.4.1.2016.11607

Chang, K., Kuo, N., Hsu, C., \& Cheng, Y. (2014). The Impact of Website Quality and Perceived Trust on Customer Purchase Intention in the Hotel Sector: Website Brand and Perceived Value as Moderators, International Journal of Innovation, Management and Technology, 5(4), 255-260.

Ghafiki, R., \& Setyorini, R. (2017). Pengaruh Kualitas Website Terhadap Keputusan Pembelian pada Situs Bukalapak.com, Jurnal Akuntansi dan Keuangan Indonesia, 9(2), 678-686.

Haekal, A., \& Widjajanta, B. (2016). Pengaruh Kepercayaan dan Persepsi Risiko Terhadap Minat Membeli Secara Online pada Pengunjung Website Classifieds di Indonesia, Journal of Business Management and Enterpreneurship Education, 1(1), 181-193. https://doi.org/10.17509/jbme.v1i1.2287

Hair, J. F. (2009). Multivariate data analysis. New Jersey: Prentice-Hall.

Hasbullah, N. A., Osman, A., Abdullah, S., Salahuddin, S. N., Ramlee, N, F., \& Soha, H. M. (2016). The Relationship of Attitude, Subjective Norm and Website Usability on Consumer Intention to Purchase Online: An Evidence of Malaysian Youth, Journal of Procedia Economics and Finance, 35, 493-502. https://doi.org/10.1016/S2212-5671(16)00061-7

Hendrayana, I W., \& Santika, I. W. (2016). Pengaruh Kualitas Laman, Persepsi Kepercayaan, dan Persepsi Kualitas Produk Terhadap Niat Membeli Secara Online pada Situs Belanja Online Zalora di Denpasar, E-Jurnal Manajemen Universitas Udayana, 4(2), 320-335.

Idris, I., \& Kasmo, A. B. P. (2017). Pengaruh Sikap, Norma Subjektif dan Persepsi Kontrol Perilaku Terhadap Minat Kepemilikan Kartu Kredit, Jurnal Manajemen dan Bisnis Indonesia, 4(3), 306-332. https://doi.org/10.31843/jmbi.v4i3.126

Jogiyanto, H., 2007. Metodologi Penelitian Sistem Informasi, Penerbit Andi, Yogyakarta.

Kautonen, T., \& Karjaluoto, H. (2008). Trust and New Technologies: Marketing and Management on the Internet and Mobile Media, Edward Elgar, UK.

Kim, S., Shaw, T., \& Schneider, H. (2003). Web Site Design Benchmarking within Industry Groups, Journal of Internet Research, 13(1), 1726. https://doi.org/10.1108/10662240310458341

Kotler, P., \& Keller, K. L. (2009). Manajemen Pemasaran, Erlangga, Jakarta.

Morissan, A. M. (2010). Periklanan Komunikasi Pemasaran Terpadu, Penerbit Kencana, Jakarta.

Noronha, A. K., \& Rao, P. S. (2017). Effect of Website Quality on Customer Satisfaction and Purchase Intention in Online Travel Ticket Booking Websites, Journal of Scientific \& Academic 
Ady Achadi et al., Pengaruh Kualitas Website E-Commerce, Kepercayaan, Persepsi Risiko dan Norma Subyektif terhadap Minat Beli Secara Online di bukalapak.com
Publishing,
$7(5)$,
$168-173$.

10.5923/j.mm.20170705.02

Peter, J. P., \& Olson, J. C. (2012). Perilaku Konsumen dan Strategi Pemasaran, Salemba Empat, Jakarta.

Sugiyono, S. (2014). Metode Penelitian Kuantitatif, Kualitatif dan $R \& D$, Alfabeta, Bandung.

Sutisna, S. (2005). Manajemen Pemasaran, Indeks, Jakarta. 